\title{
Invasion of the Asian Ladybird Harmonia axyridis (Pallas, 1773) in the European Part of Russia
}

\author{
Ilia Zakharov ${ }^{1 *}$, Alexandr Ruchin ${ }^{2}$, Leonid Egorov ${ }^{3}$, Denis Romanov $^{1}$ and Alexey Sazhnev ${ }^{4}$ \\ ${ }^{1}$ Department of Animal Genetics, Vavilov Institute of General Genetics Russian Academy of Sciences (RAS), Moscow, \\ Russia, ${ }^{2}$ Mordovia State Nature Reserve and National Park "Smolny", Saransk, Russia, ${ }^{3}$ Prisursky State Nature Reserve, \\ Cheboksary, Russia, ${ }^{4}$ Department of Enthomology, Papanin Institute for Biology of Inland Waters Russian Academy of \\ Sciences (RAS), Borok, Russia
}

OPEN ACCESS

Edited by:

Danny Haelewaters, Ghent University, Belgium

Reviewed by:

Peter Michael James Brown Anglia Ruskin University, United Kingdom Alois Honek,

Crop Research Institute (CRI), Czechia

*Correspondence: llia Zakharov iaz34@mail.ru

Specialty section:

This article was submitted to

Global Biodiversity Threats,

a section of the journal

Frontiers in Conservation Science

Received: 10 July 2021 Accepted: 27 September 2021 Published: 25 October 2021

Citation:

Zakharov I, Ruchin A, Egorov L, Romanov D and Sazhnev A (2021)

Invasion of the Asian Ladybird Harmonia axyridis (Pallas, 1773) in the

European Part of Russia.

Front. Conserv. Sci. 2:739313

doi: 10.3389/fcosc.2021.739313
The natural range of the Asian ladybird Harmonia axyridis (Pallas, 1773) covers the territories of China, Mongolia, Korea, Japan, and Russia (Far East, Southern Siberia, and Altai). Since the early 1980's, the global invasion of $H$. axyridis began, first on the territory of the United States, from where the Asian ladybird spread to South America, Africa, and Europe. By 2016, this species occupied all of Western Europe with the exception of its northern and southern regions. Penetration of $H$. axyridis on the territory of the Russian Federation (Kaliningrad) was discovered in 2010, and since 2011, the species has spread to the Black Sea coast. This report presents our data on the distribution of Harmonia axyridis in central Russia, from its western borders, to the Volga River. The occupation of this huge territory by this species occurred mainly in the last 3 years-2018-2020. The rate of movement of the species on the territory of the European part of Russia is about $200 \mathrm{~km} /$ year.

Keywords: Asian ladybug, Harmonia axyridis, invasion, propagation speed, European part of Russia

\section{INTRODUCTION}

The natural range of the Asian ladybird Harmonia axyridis (Pallas, 1773) (Coleoptera: Coccinellidae) covers the following territories: North-Eastern and Central China, Mongolia, Korea, Japan, Eastern Kazakhstan, and in Russia-the Far East, southern Siberia, Tyva, and Altai (Orlova-Bienkowskaja et al., 2015; Blekhman and Goryacheva, 2017; Andrianov et al., 2018). In the early 1980's, the global invasion of H. axyridis began first in the United States (Koch et al., 2006), from where the Asian ladybird spread to South America, Africa, and Europe where it mixed with populations used in biological protection of greenhouse crops that escaped into the open (Lombaert et al., 2010; Roy et al., 2016). In Europe, invasive populations of H. axyridis were discovered in the early 2000's (Adriaens et al., 2003), and by 2016, this species occupied all of Western Europe except for its northernmost and southernmost regions (Roy et al., 2016).

In the European part of Russia, the occurrence of H. axyridis was observed from 2004 to 2006 in the territory of the Belgorod Region (Binkovskaya, 2004; Orlova-Bienkowskaja, 2013). In 2010, mass reproduction of the species was recorded by one of the authors in Kaliningrad (Zakharov et al., 2011). The presence and reproduction of $H$. axyridis have been observed since 2011 on the Black Sea coast of the Caucasus (Orlova-Bienkowskaja, 2013; Ukrainsky, 2013) and since 2012-2013 in the Krasnodar Territory (Korotyaev, 2015a,b). During the same period, there were reports of $H$. axyridis finds in Ukraine [since 2007-(Nekrasova and Tytar, 2009; Verizhnikova and Shylova, 2013)], in Belarus [since 2011—(Kruglova, 2015; Kruglova and Sinchuk, 2017)], and in Latvia [since 2009-(Barševskis, 2009)]. 
This report presents the authors' data on the distribution of $H$. axyridis in central Russia, from its western borders to the Volga River. The discussed species captured this huge territory mainly in the last 3 years $-2018-2020$.

\section{MATERIALS AND METHODS}

The presence of $H$. axyridis was recorded during the implementation of special collections of coccinellids or when collecting other insects. Beetles $H$. axyridis were collected at the stages of imago, pupae, and last instar larvae. Collections were carried out on various shrubs and trees, in cities-mainly on lime trees (Tilia sp.), as well as during the autumn flight and in wintering areas. Methods of collecting beetles and keeping them in the laboratory are described in Andrianov et al. (2018). In the collections of $H$. axyridis, where morphs were counted, three phenotypes were distinguished: succinea (yellow or red with a different number of black spots), spectabilis, and conspicua (both are black, with four and two red spots, respectively) and axyridis (black with many red/yellow spots). Among the succinea morphs, the proportion of individuals without spots was taken into account (see Table 2).

\section{RESULTS AND DISCUSSION}

Information about the materials collected by the authors of this paper and the collections of other researchers is presented in Table 1 and the map (Figure 1). It can be seen that $H$. axyridis

TABLE 1 | Collections of Harmonia axyridis in 2018-2020 years in the European part of Russia.

\begin{tabular}{|c|c|c|c|c|c|}
\hline $\begin{array}{l}\text { Collection sites } \\
\text { (westerly to easterly) }\end{array}$ & $\begin{array}{l}\text { Geographical } \\
\text { coordinates } \\
\text { (lat/long) }\end{array}$ & $\begin{array}{l}\text { Dates of } \\
\text { collections }\end{array}$ & $\begin{array}{l}\text { Collections - } \\
\text { solitary/mass }\end{array}$ & $\begin{array}{l}\text { Population } \\
\text { state }\end{array}$ & $\begin{array}{l}\text { Collector or } \\
\text { publication }\end{array}$ \\
\hline Kaliningrad & $54.71 / 20.51$ & 08.2019 & Mass & $\mathrm{B}$ & I.A. Zakharov \\
\hline Kursk region & $52.31 / 35.38$ & 10.06.2019 & Solitary & B & Ruchin et al., 2020 \\
\hline Oryol & $52.96 / 36.08$ & 08.10 .2018 & Solitary & A & Sazhnev et al., 2020 \\
\hline Kaluga & $54.53 / 36.17$ & 10.2018 & Solitary & $\mathrm{C}$ & Ruchin et al., 2020 \\
\hline Moscow, Gagarin square & $55.71 / 37.58$ & 14.10 .2020 & Mass & $\mathrm{C}$ & I.A. Zakharov \\
\hline Moscow, South district & $55.61 / 37.68$ & 09.2020 & Mass & B & I.A. Zakharov \\
\hline Moscow, Zhulebino district & $55.69 / 37.84$ & 06-08.2020 & Mass & $\mathrm{B}$ & D.A. Romanov \\
\hline Sochi, Lazarevskoe & $43.91 / 39.33$ & 06.2019 & Mass & B & D.A. Romanov \\
\hline Rostov-on-Don & 47.22 / 39.72 & 10.2019 & Mass & A & D.E. Romanov \\
\hline Ryazan region & $53.59 / 40.03$ & 10.2019 & Mass & $\mathrm{D}$ & I.I. Goryacheva \\
\hline Ryazan region & $54.21 / 40.98$ & $6-13.10 .2020$ & Solitary & $A, D$ & A.B. Ruchin \\
\hline Ryazan region & $54.07 / 41.45$ & $6-13.10 .2020$ & Solitary & $A, D$ & A.B. Ruchin \\
\hline Tambov region & $52.49 / 42.80$ & 24.08 .2019 & Solitary & A & Ruchin et al., 2020 \\
\hline Republic of Mordovia, Pushta & $54.72 / 43.23$ & $\begin{array}{l}10.2019 \\
10.2020\end{array}$ & Mass & $\mathrm{D}$ & A.B. Ruchin \\
\hline Saransk & $54.18 / 45.18$ & $\begin{array}{l}10.2019 \\
10.2020\end{array}$ & Mass & $A, C, D$ & $\begin{array}{l}\text { A.B. Ruchin } \\
\text { E.A. Lobachev } \\
\text { A.V. Meshcheryakova }\end{array}$ \\
\hline Volgograd region & $49.55 / 45.07$ & 15.09 .2018 & Solitary & A & Ruchin et al., 2020 \\
\hline Saratov & $51.52 / 45.98$ & 06.09.2019 & Mass & A & Ruchin et al., 2020 \\
\hline Penza region & $52.78 / 46.80$ & 10.07.2018 & Mass & A & Ruchin et al., 2020 \\
\hline Republic of Chuvashia & $54.51 / 46.35$ & 23.08.-25.10.2019 & Solitary & A & Egorov et al., 2019 \\
\hline Republic of Chuvashia & $55.00 / 46.42$ & 14.10 .2020 & Solitary & A & L.V. Egorov \\
\hline Cheboksary & $56.08 / 47.08$ & 14.10.2020 & Solitary & A & N.V. Borisova \\
\hline Cheboksary & $56.08 / 47.15$ & 23.08.-25.10.2019 & Solitary & A & Egorov et al., 2019 \\
\hline Republic of Chuvashia & $54.51 / 47.22$ & 27.06.2020 & Solitary & A & L.V. Egorov \\
\hline Ulyanovsk region & $53.08 / 47.38$ & 25.07.2019 & Solitary & A & Ruchin et al., 2020 \\
\hline Ulyanovsk, & $54.18 / 48.07$ & 3.10 .2020 & Solitary & $A$ & Kichigin, 2020 \\
\hline Astrakhan & $46.35 / 48.03$ & 10.04.2019 & Solitary & A & Ruchin et al., 2020 \\
\hline Kazan & $55.85 / 49.07$ & 30.09 .2019 & Solitary & B & Ruchin et al., 2020 \\
\hline Samara region & $53.74 / 49.45$ & 27.06 .2020 & Solitary & A & D.S. Pasynkova \\
\hline Samara region & $53.46 / 49.84$ & 29.08.2019 & Solitary & $A$ & Egorov et al., 2019 \\
\hline Republic of Udmurtia & $58.13 / 52.67$ & 24.09.2019 & Solitary & A & Sazhnev et al., 2020 \\
\hline
\end{tabular}

Population state: A - active, only imago, B - reproduction (presence of pupae and larvae), $C$ - winter flight, D - wintering; solitary/mass - single find / mass collection. 


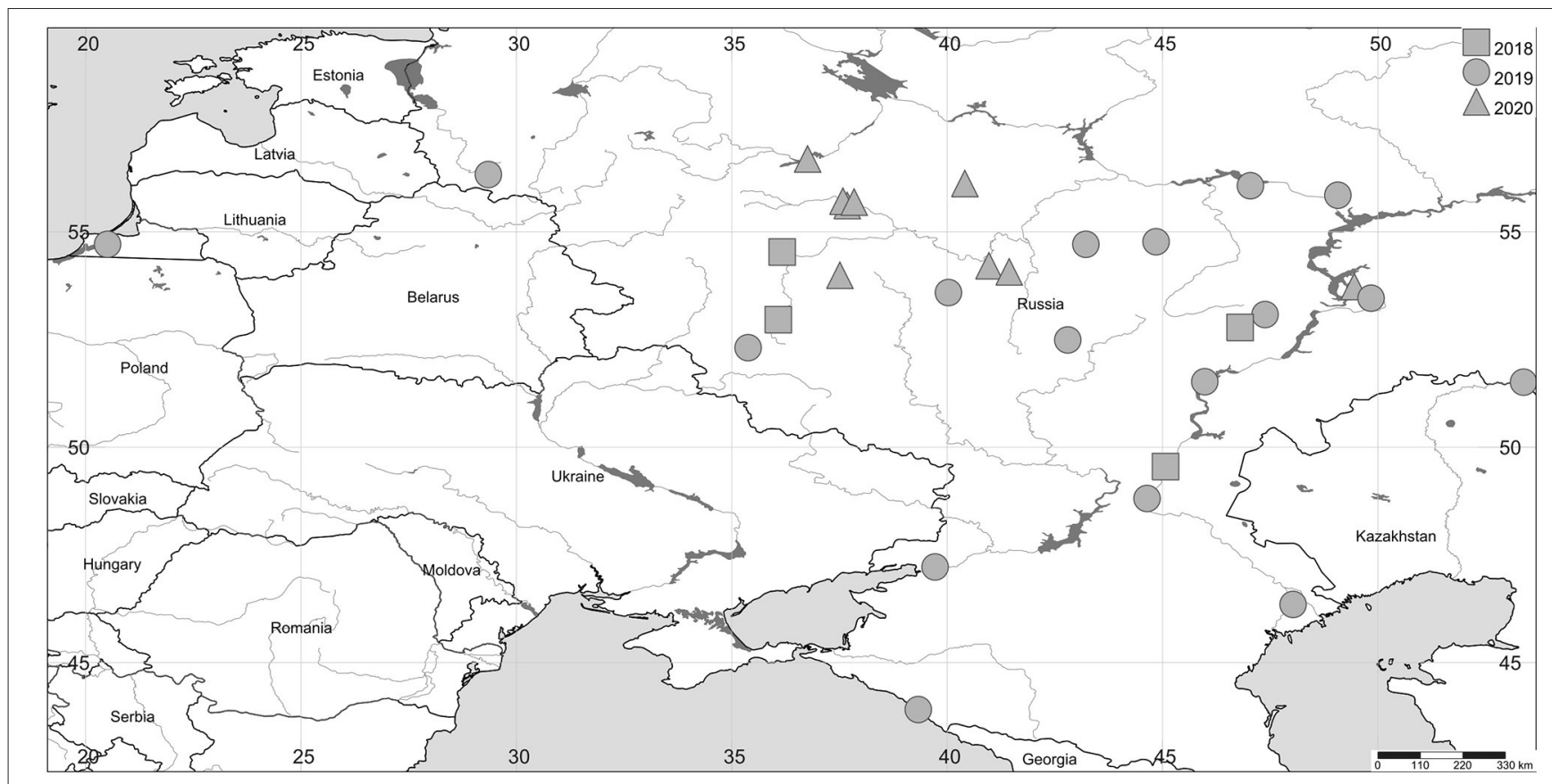

FIGURE 1 | Harmonia axyridis distribution in the European part of Russia (2018-2020).

TABLE 2 | Constitution of Harmonia axyridis populations, number and percent of morphs.

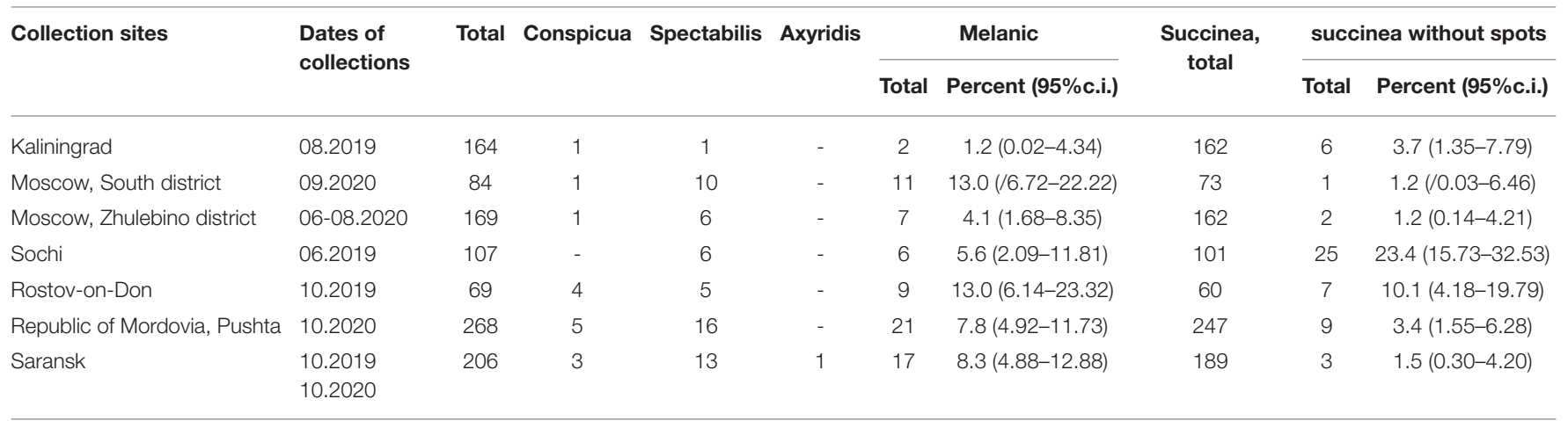

95\%c.i., 95\% "exact" confidence interval.

occupied a huge territory-from the western borders of the Russian Federation to the Volga.

Almost exclusively the morphs found commonly in Europe-succinea, spectabilis, conspicua-were present in all the collections, with $f$. succinea dominating. The West Siberian morph axyridis was found only once-in Saransk (one individual). The least number of melanics (spectabilis, conspicua) was in Kaliningrad. The proportion of beetles of the succinea morph without spots was the greatest in Sochi in comparison with other populations (Table 2). This suggests that the settlement of the Black Sea coast of the Caucasus occurred not only from the west, as in other regions, but also from the south, from Asia Minor.

It is known that in the new territories occupied by H. axyridis, this species successfully competes with the local Coccinellidae, as a result of which the number of the latter decreases
TABLE 3 | The ratio of three species of coccinellids in collections in Moscow, Zhulebino district (end of June - August 2020).

\begin{tabular}{lccc}
\hline Species & Number of larvae & Number of pupae & Total \\
\hline Harmonia axyridis & 21 & 148 & 169 \\
Adalia bipunctata & 56 & 457 & 513 \\
Adalia decempunctata & 14 & 91 & 105 \\
\hline
\end{tabular}

(Brown and Roy, 2018). In two geographical locations, the authors calculated the ratio of $H$. axyridis and local species of the genus Adalia [Adalia bipunctata (Linnaeus, 1758) and Adalia decempunctata (Linnaeus, 1758)], which occur on the same plants with aphid colonies and reproduce at the same 
time. In Kaliningrad (August 2019), where H. axyridis were collected, Adalia ladybirds were not found at all, although in previous years, before the appearance of $H$. axyridis here, Adalia findings were numerous (observations of IZ). The same was noted by one of the authors (IZ, unpublished) in Munich (Germany), where in 2015, with a significant number of found $H$. axyridis, Adalia ladybirds were not found. In Moscow, where mass reproduction of $H$. axyridis was observed for the first time in 2020, Adalia ladybirds still predominate among coccinellids (Table 3). These data should be supplemented in subsequent years.

The rate of progress of the species was estimated from the findings in Kaliningrad (2010), the first breeding colony in Moscow [2015-(Zakharov, 2015)], and in Saratov [2019(Sazhnev et al., 2020)]. Taking into account the distance from Kaliningrad to Moscow $(1,100 \mathrm{~km})$ and from Kaliningrad to Saratov $(1,750 \mathrm{~km})$, the propagation speed is about $200 \mathrm{~km} /$ year. At this speed, beetles can spread both naturally (Jeffries et al., 2013) and using passing transport. The rate of spread calculated here is the same as that calculated in other parts of Europe (Brown et al., 2011).

Given the wide adaptability of $H$. axyridis to various environmental and climatic conditions, one can expect the spread of this species in the coming years to the north, at least

\section{REFERENCES}

Adriaens, T., Branquart, E., and Maes, D. (2003). The multicoloured Asian ladybird Harmonia axyridis Pallas (Coleoptera: Coccinellidae), a thread for native aphid predators in Belgium? Belg. J. Zool. 133, 195-196. doi: 10.1093/jis/3.1.32

Andrianov, B., Blekhman, A., Goryacheva, I., Zakharov-Gezekhus, I., and Romanov, D. (2018). "Chapter 1 Biological characteristics of Harmonia axyridis Pall," in Asian Ladybird Harmonia axyridis: Global Invasion, ed I. A. ZakharovGezekhus (Moscow: KMK Scientific Press Ltd.), 143.

Barševskis, A. (2009). Multicoloured Asian lady beetle [Harmonia axyridis (Pallas, 1773)] (Coleoptera: Coccinellidae) for the first time in the fauna of Latvia. Balt. J. Coleopterol. 9, 135-138.

Binkovskaya, O. V. (2004). Coccinellid Beetles of Forest Ecosystems in the South of the Central Russian Upland. Abstr. of diss. for the degree of phD. Voronezh: BelGU Publ, 21.

Blekhman, A. V., and Goryacheva, I. I. (2017). Native area and biological features of invasive ladybird Harmonia axyridis. Biol. Bull. Rev. 7, 103-112. doi: 10.1134/S2079086417020025

Brown, P. M. J., and Roy, H. E. (2018). Native ladybird decline caused by the invasive harlequin ladybird Harmonia axyridis: evidence from a long-term field study. Ins. Conserv. Divers. 11, 230-239. doi: 10.1111/icad.12266

Brown, P. M. J., Thomas, C., Lombaert, E., Jeffries, D. L., Estoup, A. and Lawson Handley, L.-J. (2011). The global spread of Harmonia axyridis: distribution, dispersal and routes of invasion. Biocontrol 56, 623-642. doi: 10.1007/s10526-011-9379-1

Egorov, L. V., Podshivalina, V. N., Borisova, N. V., and Ruchin, A. B. (2019). Harmonia axyridis (Pallas, 1773) (Coleoptera: Coccinellidae) a new alien species for the Volga region fauna. Eversmannia 59-60, 73.

Jeffries, D. L., Chapman, J., Roy, H. E., Humphries, S., Harrington, R., Brown, P. M. J., et al. (2013). Characteristics and drivers of high-altitude ladybird flight: insights from vertical-looking entomological radar. PLoS ONE 8:e82278. doi: 10.1371/journal.pone.0082278

Kichigin, R. M. (2020). "Observation of the invasive species of ladybirds Harmonia axyridis (Pallas, 1773) in the Ulyanovsk region (Coleoptera: Coccinellidae)," in Nature of the Simbirsk Volga region. Sat. Scientific Works of the XXII to St. Petersburg (in 2019, H. axyridis was not there yet) and to the east, to the Urals.

If $H$. axyridis spreads to the east beyond the Urals, it will be possible to observe an interesting natural experiment, when the populations of two subspecies of $H$. axyridis, which clearly differ in morphological features [color and pattern on the elytra(Blekhman and Goryacheva, 2017)] and in mitotypes-variants of mitochondrial DNA (Zakharov et al., 2011), unite in the Tomsk-Novosibirsk area (the western edge of the native range). Given the rate of spread of $H$. axyridis, one can expect that nature will stage this population-genetic experiment in the next 10 years.

\section{DATA AVAILABILITY STATEMENT}

The original contributions presented in the study are included in the article, further inquiries can be directed to the corresponding authors.

\section{AUTHOR CONTRIBUTIONS}

IZ conceived the project, designed methodology, and led the writing of the manuscript. IZ, AR, LE, DR, and AS contributed to ladybird collection and identification. All authors contributed critically to the drafts and gave final approval for publication.
Interregional Scientific-pr. conf. "Natural science research in the Simbirsk Ulyanovsk region.” Ulyanovsk: Corp. Prom. Techn., 104-106.

Koch, R. L., Venette, R. C., and Hutchison, V. D. (2006). Invasions by Harmonia axyridis (Pallas) (Coleoptera: Coccinellidae) in the Western Hemisphere: implications for South America. Neotrop. Entomol. 35, 421-434. doi: 10.1590/S1519-566X2006000400001

Korotyaev, B. A. (2015a). On the distribution dynamics of some beetles (Coleoptera: Coccinellidae, Bruchidae, Curculionidae) in the plains of the Northwestern Caucasus, Russia. Entomol. Rev. 95, 137-140. doi: $10.1134 /$ S0013873815010157

Korotyaev, B. A. (2015b). On high abundance of the Harlequin lady beetle, Harmonia axyridis (Pall.) (Coleoptera, Coccinellidae), in the plains of the Northwestern Caucasus, Russia. Entomol. Rev. 95, 1317-1319. doi: 10.1134/S0013873815090195

Kruglova, O. Y. (2015). Phenetic features of invasive ladybeetle's Harmonia axyridis Pallas (Coleoptera, Coccinellidae) groups in Belarus. Proc. Belarus. State Univers. 10, 327-335.

Kruglova, O. Y., and Sinchuk, A. V. (2017). "Variability of different groups of polymorphic characters of the invasive species Harmonia axyridis (Pallas, 1773) (Coleoptera, Coccinellidae) in Belarus," in Results and Prospects of the Development of Entomology in Eastern Europe: A Collection of Articles of the II International Scientific and Practical Conference (Minsk, September 6-8, 2017) (Minsk: A.N. Varaksin), 249-264.

Lombaert, E., Guillemaud, T., Cornuet, J. M., Malausa, T., Facon, B., and Estoup, A. (2010). Bridgehead effect in the worldwide invasion of the biocontrol harlequin ladybird. PloS ONE 5:e9743. doi: 10.1371/journal.pone.0009743

Nekrasova, O. D., and Tytar, V. M. (2009). A record of the harlequin ladybird, Harmonia axyridis (Pallas) (Coleoptera: Coccinellidae), in Kyiv. Vestn. Zool. 43:538.

Orlova-Bienkowskaja, M. J. (2013). Dangerous invasive harlequin ladybird Harmonia axyridis (Pallas, 1773) (Coleoptera, Coccinellidae) in the European Russia. Rus. J. Biol. Invas. 4, 190-193. doi: 10.1134/S20751117130 30107

Orlova-Bienkowskaja, M. J., Ukrainsky, A. S., and Brown, P. M. J. (2015). Harmonia axyridis (Coleoptera: Coccinellidae) in Asia: a re-examination of the 
native range and invasion to southeastern Kazakhstan and Kyrgyzstan. Biol. Invasions 17, 1941-1948. doi: 10.1007/s10530-015-0848-9

Roy, H. E., Brown, P. M. J., Adriaens, T., Berkvens, N., Borges, I., ClusellaTrullas, S., et al. (2016). The harlequin ladybird, Harmonia axyridis: global perspectives on invasion history and ecology. Biol. Invas. 18, 997-1044. doi: 10.1007/s10530-016-1077-6

Ruchin, A. B., Egorov, L. V., Lobachev, E. A., Lukiyanov, S. V., Sazhnev, A. S., and Semishin, G. B. (2020). Expansion of Harmonia axyridis (Pallas, 1773) (Coleoptera: Coccinellidae) to European part of Russia in 2018 - 2020. Balt. J. Coleopterol. 20, 51-60.

Sazhnev, A. S., Anikin, V. V., and Zolotukhin, V. V. (2020). Overwintering and new records of invasive harlequin ladybird Harmonia axyridis (Pallas, 1773) (Coleoptera: Coccinellidae) after mass expansion to European part of Russia in 2018-2019. Rus. J. Ecosyst. Ecol. 5, 43-48. doi: 10.21685/2500-0578-2020-4-4

Ukrainsky, A. S. (2013). The multicoloured Asian lady beetle Harmonia axyridis Pall. (Coleoptera, Coccinellidae) in North Caucasus, Russia. Euroas. Entomol. J. 12, 35-38.

Verizhnikova, I. V., and Shylova, K. A. (2013). "Consequences of entomophage Harmonia axyridis Pall. (Coleoptera, Coccinellidae) introduction and its predicted area of acclimatization," in The Urgent Ecological and Environmental Management Problems: Coll. Res. Articles (Moscow: PFUR), 65-68.

Zakharov, I. A. (2015). Harmonia in Moscow. Priroda 11, 92-93.
Zakharov, I. A., Goryacheva, I. I., and Suvorov, A. (2011). Mitochondrial DNA polymorphism in invasive and native populations of Harmonia axyridis. Eur. J. Environ. Sci. 1, 15-18. doi: 10.14712/23361964.2015.59

Conflict of Interest: The authors declare that the research was conducted in the absence of any commercial or financial relationships that could be construed as a potential conflict of interest.

Publisher's Note: All claims expressed in this article are solely those of the authors and do not necessarily represent those of their affiliated organizations, or those of the publisher, the editors and the reviewers. Any product that may be evaluated in this article, or claim that may be made by its manufacturer, is not guaranteed or endorsed by the publisher.

Copyright (c) 2021 Zakharov, Ruchin, Egorov, Romanov and Sazhnev. This is an open-access article distributed under the terms of the Creative Commons Attribution License (CC BY). The use, distribution or reproduction in other forums is permitted, provided the original author(s) and the copyright owner(s) are credited and that the original publication in this journal is cited, in accordance with accepted academic practice. No use, distribution or reproduction is permitted which does not comply with these terms. 